\title{
Evaluation of the seaweeds Chondrus crispus and Ulva lactuca as functional ingredients in gilthead seabream (Sparus aurata)
}

Inês Guerreiro1\&

Rui Magalhães $1,2 \&$

Filipe Coutinho1\&

Ana Couto1\&

Sara Sousaz\&

Cristina Delerue-Matos $3 \&$

Valentina F. Domingues $3 \&$

Aires Oliva-Teles $1,2 \&$

Helena Peres $1,2 R$

\section{Abstract}

The effect of a dietary incorporation of the seaweeds Ulva lactuca and Chondrus crispus as functional ingredients was evaluated in gilthead seabream (Sparus aurata) juvenile growth, feed efficiency, muscle lipid composition, intermediary metabolism, oxidative status and gut histomorphology. Fish (15 g initial body weight) were fed with isoproteic (46\%) and isolipidic (18\%) diets with fish meal (FM) and plant feedstuffs (PF) (27:73 protein from FM:PF) as main protein sources (control diet). Three other diets were formulated similar to the control but including 5\% U. lactuca, 5\% C. crispus or $2.5 \%$ of both algae (diets Ulva, Chondrus and Mix, respectively). Dietary incorporation of Ulva did not affect growth performance $(P>0.05)$ while it leads to higher muscle $\Sigma$ SFA (saturated fatty acids); and liver lipid peroxidation (LPO). Moreover, lower muscle ¿PUFA (polyunsaturated fatty acids) and plasma glucose was observed. Dietary incorporation of Chondrus leads to lower growth; whole-body dry matter and lipid content; muscle $\Sigma$ PUFA and $\omega 3$ fatty acids; and plasma glucose. In addition, higher muscle $\Sigma$ MUFA (monounsaturated fatty acids); and liver LPO was observed. Dietary incorporation of both algae (Mix) led to lower growth; whole-body lipid content; muscle ¿PUFA and $\omega 3$ fatty acids; plasma glucose; and hepatic PK (pyruvate kinase) and HOAD (3-hydroxyacyl-CoA dehydrogenase). Furthermore, it leads to higher muscle $\Sigma$ SFA and ¿MUFA; and liver LPO. Overall, no beneficial effects of including the tested seaweeds in the diets was observed, while oxidative status was negatively affected in all dietary treatments. 


\section{Introduction}

A functional ingredient is a feed component that has physiologic effects beyond that of nutrient effects (Roberfroid 2000). Functional ingredients are reported to improve growth, feed efficiency, stress tolerance, disease resistance and health status in fish (Oliva-Teles 2012), and are being increasingly used in the feed industry. There is also intensive research on functional ingredients to be included in aquafeeds (Kiron 2012), and seaweeds are considered to have high potential as functional ingredients (Holdt and Kraan 2011). Besides having potential of contributing to macronutrients requirements, seaweeds are rich in polysaccharides, minerals and some vitamins, containing also bioactive compounds with antibacterial, antiviral and antifungal properties, which could be used for enhancing the production and health status of fish, making them functional ingredients (Holdt and Kraan 2011; Makkar et al. 2016). Seaweed polysaccharides concentration and protein content differ greatly among species, while lipids are poorly represented (Holdt and Kraan 2011). Seaweeds include brown, red and green algae, being Chondrus crispus, a red alga and Ulva lactuca, a green alga (Collén et al. 2014; Makkar et al. 2016). U. lactuca polysaccharides contents range from 15 to $65 \%$, protein from 4 to $44 \%$ and lipids from 0.3 to $1.6 \%$, while $C$. crispus polysaccharides range from 55 to $66 \%$, protein from 6 to $29 \%$ and lipids from 0.7 to $3 \%$ (Holdt and Kraan 2011).

Dietary inclusion of both red and green algae was already reported as improving performance of several fish species, such as striped mullet (Mugil cephalus) fed up to $25 \%$ U. lactuca, European seabass (Dicentrarchus labrax) fed 5\% of U. lactuca or Pterocladia capillacea, Nile tilapia (Oreochromis niloticus) fed 5\% Ulva rigida, Atlantic salmon (Salmo salar) fed 10\% Gracilaria chilensis and white spotted snapper (Lutjanus stellatus) fed 5\% U. lactuca (Wassef et al. 2001, 2013; Ergün et al. 2009; Lozano et al. 2016; Zhu et al. 2016). Nonetheless, worse growth performance was also reported with dietary inclusion of seaweeds, for instance in white spotted snapper fed with 10, 15 or $20 \%$ U. lactuca, tilapia fed with 15 or $20 \%$ Ulva spp. or $10 \%$ Gracilaria vermiculophylla and European seabass fed with 10\% Gracilaria cornea (Valente et al. 2006; Marinho et al. 2013; Silva et al. 2015; Zhu et al. 2016).

Gilthead seabream (Sparus aurata) is a carnivorous marine fish, feeding essentially on molluscs and crustaceans, but accessorily, it can adapt its diet to other food items available in the habitat, including seaweeds. Therefore, seaweeds are part of gilthead seabream natural diet (Arias 1980; Pita et al. 2002). Due to gilthead seabream importance in Mediterranean aquaculture, some studies arise about the use of seaweeds as alternative or functional ingredient in this species (Wassef et al. 2005; Emre et al. 2013; Sáez et al. 2013; Ribeiro et al. 2015; Rico et al. 2016; Vizcaíno et al. 2016; Magnoni et al. 2017; Shpigel et al. 2017). For instance, $U$. lactuca was used to replace up to $15 \%$ fish meal in juveniles diets without compromising growth (Shpigel et al. 2017). Also, in fry, U. lactuta included in the diets at $15 \%$ did not affect growth performance, while at a dietary inclusion of 5\% it improved survival rate after $5 \mathrm{~min}$ of air-exposure (Wassef et al. 2005). Further, dietary inclusion of $25 \%$ U. rigida lead to growth improvement (Vizcaíno et al. 
2016), however, response to dietary Ulva inclusion was not linear but quadratic, with the lowest performance being obtained with $15 \%$ dietary inclusion level. In addition, dietary U. rigida supplementation at 5\% (Vizcaíno et al. 2016) or at 4\% (Emre et al. 2013) did not affect growth or feed utilisation. Dietary supplementation with $5 \%$ heat-treated $G$. vermiculophylla and $U$. lactuca were also reported to enhance acute hypoxia tolerance (Magnoni et al. 2017). Thus, it seems that fish response to dietary seaweed inclusion is dependent on seaweed species, dose and rearing conditions, besides being speciesdependent.

Chondrus crispus is commercially harvested along the Pacific and Atlantic coasts and is also grown on land. It has a high-protein content and is rich in carrageenan, a polysaccharide with health-promoting characteristics (Liu et al. 2013; Kulshreshtha et al. 2014). In fact, $C$. crispus has been considered a potential prebiotic for layer hens (Kulshreshtha et al. 2014) and it was shown to enhance the immunity and suppress the expression of quorum sensing and virulence factors of Pseudomonas aeruginosa in infected Caenorhabditis elegans (Liu et al. 2013). U. lactuca has health-promoting characteristics and adequate nutritional profile, with relatively high levels of essential amino acids and polyunsaturated fatty acids (Ortiz et al. 2006; Holdt and Kraan 2011).

Therefore, the aim of the present study was to assess the effect of dietary incorporation of $5 \% \mathrm{U}$. lactuca or C. crispus or a mix of both algae, on gilthead seabream juvenile growth, feed efficiency, muscle lipid composition, intermediary metabolism, hepatic oxidative status and gut histomorphology.

\section{Material and methods}

\section{Diets composition}

A control diet was formulated to contain $18 \%$ lipid and $46 \%$ protein using fish meal (FM) and plant feedstuffs (PF) (27:73 protein from FM:PF) as protein sources and cod liver oil as lipid source. Three other diets were formulated similar to the control but including $5 \%$ of Ulva lactuca, $5 \%$ of Chondrus crispus or $2.5 \%$ of each seaweed at the expense of wheat (diets Ulva, Chondrus and Mix, respectively). C. crispus was collected from the nearshore waters of Oporto coast and $U$. lactuca was cultivated in an integrated multi-trophic aquaculture (IMTA) system at laboratory scale (January 2017, 41 ${ }^{\circ} 9^{\prime} 49.40^{\prime} \mathrm{N} 8^{\circ} 41^{\prime}$ $\left.12.58^{\prime} \mathrm{W}\right)$. Both seaweeds were washed thoroughly with fresh water, dried in an oven at $40{ }^{\circ} \mathrm{C}$ for $72 \mathrm{~h}$ and ground to a powder before inclusion in the diets. All diet ingredients were thoroughly mixed and dry pelleted in a laboratory pellet mill (California Pellet Mill, USA) through a $3.0-\mathrm{mm}$ die. Pellets were dried in an oven at $40{ }^{\circ} \mathrm{C}$ for $48 \mathrm{~h}$ and then stored in a freezer in airtight bags until use. Ingredients and proximate composition of the experimental diets are presented in Table 1 .

Table 1 Ingredients and proximate composition of the experimental diets 


\begin{tabular}{|c|c|c|c|c|}
\hline & \multicolumn{4}{|l|}{ Diets } \\
\hline & Control & Ulva & Chondrus & Mix \\
\hline \multicolumn{5}{|l|}{ Ingredients (\% DM) } \\
\hline Fish meal' & 17.5 & 17.5 & 17.5 & 17.5 \\
\hline Corn gluten ${ }^{b}$ & 17.0 & 17.0 & 17.0 & 17.0 \\
\hline Soybean meal & 17.5 & 17.5 & 17.5 & 17.5 \\
\hline Wheat gluten ${ }^{d}$ & 10.5 & 10.1 & 10.2 & 10.1 \\
\hline Wheat meal" & 15.4 & 10.6 & 10.5 & 10.6 \\
\hline Ulva lactuca' & & 5.0 & & 2.5 \\
\hline Chandrus crispus? & & & 5.0 & 2.5 \\
\hline Taurine ${ }^{n}$ & 0.3 & 0.3 & 0.3 & 0.3 \\
\hline Lysine' & 0.3 & 0.3 & 0.3 & 0.3 \\
\hline Cod liver oil & 14.8 & 14.8 & 14.9 & 14.9 \\
\hline Vitamin mod & 1.0 & 1.0 & 1.0 & 1.0 \\
\hline Mineral mix & 1.0 & 1.0 & 1.0 & 1.0 \\
\hline Choline chloride (5096) & 0.5 & 0.5 & 0.5 & 0.5 \\
\hline Binder' & 1.0 & 1.0 & 1.0 & 1.0 \\
\hline Monocalcium phosphate ${ }^{m}$ & 3.3 & 3.4 & 3.4 & 3.4 \\
\hline \multicolumn{5}{|l|}{ Proximate analysis ( $96 \mathrm{DM}$ ) } \\
\hline Dry matter (96) & 91.0 & 89.1 & 90.7 & 89.6 \\
\hline Crude protein & 47.2 & 47.5 & 47.5 & 47.7 \\
\hline Crude fat & 18.9 & 18.7 & 18.4 & 20.0 \\
\hline Ash & 7.6 & 9.1 & 8.9 & 8.8 \\
\hline Starch & 11.7 & 7.8 & 82 & 6.9 \\
\hline Gross energy $\left(\mathrm{kJ} \mathrm{g}^{-1}\right)^{n}$ & 20.6 & 19.9 & 19.1 & 20.3 \\
\hline
\end{tabular}

$D M$, dry matter; $C P$, crude protein; $C L$, crude lipid

aSteam dried LT fish meal, Pesquera Centinela, Chile (CP 69.7\% DM; CL 7.2\% DM)

bSorgal, S.A. Ovar, Portugal (CP 70.7\%; DM CL $3.6 \%$ DM)

'Sorgal, S.A. Ovar, Portugal (CP 51.9\% DM; CL 3.7\% DM)

'Sorgal, S.A. Ovar, Portugal (CP 86.2\% DM; CL $3.0 \%$ DM)

'Sorgal, S.A. Ovar, Portugal. (CP 14.5\% DM; CL 2.4\% DM)

${ }^{f} \mathrm{CP} 21.49 \%$ DM; CL 1.71\% DM

${ }^{8} \mathrm{CP} 20.4 \%$ DM; CL $0.9 \% \mathrm{DM}$

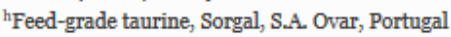

${ }^{i}$ Feed-grade lysine, Sorgal, S.A. Ovar, Portugal

jVitamins ( $\mathrm{mg} \mathrm{kg}^{-1}$ diet): retinol acetate, 18,000 (IU kg${ }^{-1}$ diet); cholecalciferol, 2000 (IU kg - 1 diet); alpha tocopherol acetate, 35 ; sodium menadione

bisulphate, 10; thiamin- $\mathrm{HCl}, 15$; riboflavin, 25; calcium pantothenate, 50; nicotinic acid, 200; pyridoxine $\mathrm{HCl}, 5$; folic acid 10; cyanocobalamin, 0.02 ;

biotin, 1.5; ascorbic acid, 50 ; inositol, 400

${ }^{\mathrm{k}}$ Minerals (mg kg-1 diet): cobalt sulphate, 1.91; copper sulphate, 19.6; iron sulphate, 200; sodium fluoride, 2.21; potassium iodide, o.78; magnesium oxide,

830 ; manganese oxide, 26; sodium selenite, 0.66 ; zinc oxide, 37.5 ; dibasic calcium phosphate, $5.93\left(\mathrm{~g} \mathrm{~kg}^{-1}\right.$ diet); potassium chloride, 1.15 ( $\mathrm{g} \mathrm{kg}{ }^{-1}$ diet);

sodium chloride, $0.40\left(\mathrm{~g} \mathrm{~kg}^{-1}\right.$ diet $)$

${ }^{1}$ Liptosa, Madrid, Spain

mSorgal, S.A. Ovar, Portugal

${ }^{n}$ Gross energy calculated based on theoretical values ( $\mathrm{CP}_{23} .6 \mathrm{~kJ} \mathrm{~g}^{-1} ; \mathrm{CL} 39.5 \mathrm{~kJ} \mathrm{~g}^{-1}$; carbohydrates $17.2 \mathrm{~kJ} \mathrm{~g} \mathrm{~g}^{-1}$ )

\section{Growth trial}

The experiment was performed at the Marine Zoology Station, Porto University, Portugal, with gilthead seabream (Sparus aurata) juveniles obtained from a commercial fish farm (Maresa S.A., Ayamonte, Huelva, Spain). The trial was performed in a recirculating water system equipped with 12 cylindrical fibreglass tanks with 100 -L water capacity and thermoregulated to $23.0 \pm 1.0^{\circ} \mathrm{C}$. Tanks were supplied with a continuous flow of filtered seawater (2.5-3.5 $\mathrm{L} \mathrm{min}^{-1}$ ) of $35 \pm 1 \mathrm{~g} \mathrm{~L}^{-1}$ salinity and dissolved oxygen was kept near saturation $\left(7 \mathrm{mg} \mathrm{L}^{-1}\right)$. After a quarantine period of 1 month, fish were transferred to the experimental system and adapted to the experimental conditions for 15 days. Thereafter, 20 gilthead seabream with an initial mean body weight of $15.0 \pm 0.01 \mathrm{~g}$ were distributed to each tank and the experimental diets randomly assigned to triplicate groups. The trial lasted 8 weeks, and during that period, the fish were fed by hand, twice daily (9:00 and 16:00), 6 days a week, until apparent visual satiation. Utmost care was taken to avoid feed 
losses. The experiment was performed by accredited scientists (following FELASA category $\mathrm{C}$ recommendations) and conducted according to the European Union directive $2010 / 63 / \mathrm{EU}$ on the protection of animals for scientific purposes.

\section{Sampling}

Five fish from the initial stock population were randomly sampled, euthanized with a sharp blow to the head and stored at $-20{ }^{\circ} \mathrm{C}$ for whole-body composition analysis. Fish in each tank were bulk-weighed at the beginning and at the end of the trial, after 1 day of feed deprivation. For that purpose, fish were slightly anaesthetised with $0.3 \mathrm{~mL} \mathrm{~L}^{-1}$ ethylene glycol monophenyl ether (ref.:8.07291.2500, Merck, USA). Three fish per tank were euthanized and sampled for morphometric parameters (liver and visceral indices) and whole-body composition analyses (fish pooled by tank). After the final weighing, fish continued to be fed for two more days to minimise manipulation stress, and then six fish from each tank were sampled $4 \mathrm{~h}$ after the morning meal. Blood from three fish per tank was collected from the caudal vein with heparinised syringes and immediately centrifuged at $10000 \times g$ for $10 \mathrm{~min}$. Plasma aliquots were frozen at $-80{ }^{\circ} \mathrm{C}$ until plasma metabolites analysis. Fish were then euthanized with a sharp blow to the head and dissected on chilled trays. Livers (two fish per tank for each set of analysis) were sampled and then stored at $-80{ }^{\circ} \mathrm{C}$ until quantification of glycogen and lipid contents, measurement of the activities of key enzymes of intermediate metabolism and of oxidative stress, and lipid peroxidation levels. The digestive tract was freed from adjacent adipose and connective tissues of two fish and a section of the distal intestine (DI, distinguished from the mid intestine by an enlarged diameter and darker mucosa) was sampled for histological evaluation. DI samples were rinsed in phosphate-buffered saline (PBS), carefully blotted dry with a paper towel, immediately fixed in phosphate-buffered formalin (4\%, $\mathrm{pH} 7.4)$ for $24 \mathrm{~h}$ and subsequently transferred to ethanol (70\%) until further processing. Muscle was collected from three fish and then stored at $-80{ }^{\circ} \mathrm{C}$ until quantification of total lipids and fatty acids profile.

\section{Chemical analysis}

Fish collected for whole-body composition were pooled by tank and dried at $60{ }^{\circ} \mathrm{C}$ until constant weight and moisture content was then calculated. Chemical analysis of wholefish and diets was performed following the Association of Official Analytical Chemists methods AOAC (2000). Dietary starch was determined according to Beutler (1984) and hepatic glycogen as described by Plummer (1987). Hepatic and muscle lipid content were determined by the method of Folch et al. (1957), using dichloromethane instead of chloroform for muscle lipid extraction.

Fatty acid methyl esters were prepared by acid-catalysed transmethylation of total lipids using boron trifluoride methanol according to Bondia-Pons et al. (2007) and analysed in a Shimadzu GC-2010 gas chromatograph (Kyoto, Japan) equipped with a FID and a Shimadzu AOC-20i autoinjector. The separation was carried out on a CP-Sil 88 capillary 
column $(60 \mathrm{~m} \times 0.25 \mathrm{~mm}$ I.D., film thickness $0.20 \mu \mathrm{m}$; (Agilent $\mathrm{J} \& \mathrm{~W}$, USA). The operating conditions were as follows: the split-splitless injector was used in a split mode with a split ratio of 1:50. The injection volume of the sample was $1.5 \mu \mathrm{L}$. The injector and detector temperatures were kept at 250 and $260{ }^{\circ} \mathrm{C}$, respectively. It was used a flow rate of $30 \mathrm{~mL} \mathrm{~min}^{-1}$ of helium as a carrier gas (Linde Sógas purity $\geq 99.999 \%$ ), $40 \mathrm{~mL} \mathrm{~min}{ }^{-1}$ of hydrogen and $400 \mathrm{~mL} \mathrm{~min}^{-1}$ of air. The thermal gradient was $100{ }^{\circ} \mathrm{C}$ for $5 \mathrm{~min}$, then increases at $1{ }^{\circ} \mathrm{C} \min ^{-1}$ until $215^{\circ} \mathrm{C}$ maintaining the same temperature for 12 min. Fatty acid methyl esters were identified by comparison with known standard mixtures (Sigma 47,885-U Supelco 37 Component FAME Mix, USA) and quantified using the software GCsolution for GC systems (Shimadzu).

\section{Plasma metabolites analysis}

Plasma cholesterol, glucose, triglycerides and total protein were analysed using enzymatic colourimetric kits from Spinreact, Girona, Spain (cholesterol kit, code 1001091; glucose kit, code 1001191; triglycerides kit, code 1001312; total proteins kit, code 1001291).

\section{Enzymatic activities}

Liver samples were homogenised on ice in six volumes of ice-cold $100 \mathrm{mM}$ Tris- $\mathrm{HCl}$ buffer containing $0.1 \mathrm{mM}$ EDTA and $0.1 \%(v / v)$ Triton X-100, $\mathrm{pH} 7.8$. Homogenates were centrifuged at $30000 \times g$ for $30 \mathrm{~min}$ at $4{ }^{\circ} \mathrm{C}$, the resultant supernatants separated in aliquots and stored at $-80{ }^{\circ} \mathrm{C}$ until use. All enzyme assays were carried out at $37{ }^{\circ} \mathrm{C}$ in a Multiskan GO microplate reader (Model5111 9200; Thermo Scientific, China). The optimal substrate and protein concentrations for measurement of maximal activity for each enzyme were established by preliminary assays. The molar extinction coefficients used for $\mathrm{H}_{2} \mathrm{O}_{2}$ and NADPH were 0.039 and $6.22 \mathrm{mM}^{-1} \mathrm{~cm}^{-1}$, respectively. Hexokinase (HK, EC 2.7.1.1), glucokinase (GK, EC 2.7.1.2), L-type pyruvate kinase (PK, EC 2.7.1.40), fructose-1,6-bisphosphatase (FBPase, EC 3.1.3.11) and malic enzyme (ME, EC 1.1.1.40) activities were determined as described in Guerreiro et al. (2014a). Superoxide dismutase (SOD, EC 1.15.1.1), catalase (CAT, EC 1.11.1.6), glutathione peroxidase (GPX, EC 1.11.1.9), glutathione reductase (GR, EC 1.6.4.2) and glucose 6-phosphate dehydrogenase (G6PD, EC 1.1.1.49) activities were determined as described by Guerreiro et al. (2014b). $\beta$-hydroxyacyl-CoA dehydrogenase (HOAD, EC 1.1.1.35) activity was determined as described in Pérez-Jiménez et al. (2009). Protein concentration in the homogenates was determined by the Bradford method (Bradford 1976) using Bio-Rad Protein Assay Dye Reagent (ref. 5000006) with bovine serum albumin as standard. Enzyme activity was expressed as milliunits, except for SOD that was expressed as units per milligram of hepatic soluble protein. Except for SOD, one unit of enzyme activity was defined as the amount of enzyme required to transform $1 \mathrm{mmol}$ of substrate per minute under the assay conditions. One unit of SOD activity was defined as the amount of enzyme necessary to produce 50\% inhibition of the ferricytochrome c reduction rate. 


\section{Lipid peroxidation (LPO)}

Malondialdehyde (MDA) concentration was used as a marker of LPO level in the liver. In the presence of thiobarbituric acid, MDA reacts producing coloured thiobarbituric acid-reacting substances (TBARS) that were measured as described in Guerreiro et al. $(\underline{2014 b})$. Results were expressed as nanomoles MDA per gram of wet tissue, calculated from a calibration curve.

\section{Histological processing and morphological evaluation}

DI samples were processed in a tissue processor (Model Citadel 2000, Thermo Scientific, China) and sectioned with a microtome using standard histological techniques and stained with haematoxylin (72611; Richard-Allan from Thermo Scientific, UK) and eosin (71211; Richard-Allan from Thermo Scientific) using an automatic slide stainer. Blind evaluation of histological preparations was performed with particular attention given to any inflammatory changes (Baeverfjord and Krogdahl 1996; Krogdahl et al. 2003), namely changes observed in mucosal folds height (FH), width and cellularity of the lamina propria (LP) and submucosa (SM), number of intraepithelial lymphocytes (IELs) and nucleus position and supranuclear vacuolization within the enterocytes (ENT). A scale-scoring system was used as described in Couto et al. (2016) with tissue scores ranging from 0 (normal) to 5 (highly modified). The overall value of histomorphological alterations was calculated by averaging scores of the parameters described above. Images were acquired with Zen software (Blue edition; Zeiss, Germany).

\section{Statistical analysis}

Data are presented as means \pm standard deviation. Statistical analysis was by one-way ANOVA. Data were tested for normality by the Shapiro-Wilk test and for homogeneity of variances by the Levene's test. When normality was not verified, values were transformed prior to ANOVA. Histological data were neither normal nor homogeneous and could not be normalised, thus the Kruskal-Wallis non-parametric test and subsequent pairwise comparison were performed. For all data, the probability level of 0.05 was used for the rejection of the null hypothesis. All statistical analysis was done using SPSS 24.0 software package for Windows (IBM, USA).

\section{Results}

Fish promptly accepted the experimental diets, and mortality during the trial was not affected by the diet $(P>0.05)$ (Table 2 ). Dietary Chondrus, but not Ulva, negatively affected growth. Feed intake, feed efficiency (FE), protein-efficiency ratio (PER) and nitrogen retention were unaffected $(P>0.05)$ by dietary seaweed inclusion.

Table 2 Growth performance and feed utilisation efficiency of gilthead seabream fed with the experimental diets 


\begin{tabular}{|l|c|c|c|c|}
\hline Diets & Control & Ulva & Chondrus & Mix \\
\hline Final body weight $(\mathrm{g})$ & $49.4 \pm 0.9 \mathrm{~b}$ & $46.7 \pm 4.2 \mathrm{ab}$ & $42.0 \pm 3.1 \mathrm{a}$ & $40.9 \pm 1.0 \mathrm{a}$ \\
\hline Mortality (\%) & $6.7 \pm 2.9$ & $10.0 \pm 10.0$ & $3.3 \pm 2.9$ & $15.0 \pm 5.0$ \\
\hline Daily growth index & $2.15 \pm 0.04 \mathrm{~b}$ & $2.02 \pm 0.19 \mathrm{ab}$ & $1.80 \pm 0.15 \mathrm{a}$ & $1.75 \pm 0.05 \mathrm{a}$ \\
\hline Feed intake $\left(\mathrm{g} \mathrm{kg}^{-1} \mathrm{ABW}_{\text {day }}{ }^{-1}\right.$ ) & $31.6 \pm 4.0$ & $34.1 \pm 6.6$ & $32.5 \pm 3.8$ & $32.4 \pm 5.1$ \\
\hline Feed efficiency $^{\mathrm{b}}$ & $0.62 \pm 0.08$ & $0.56 \pm 0.06$ & $0.52 \pm 0.06$ & $0.52 \pm 0.06$ \\
\hline Protein efficiency ratio & $1.31 \pm 0.18$ & $1.18 \pm 0.13$ & $1.10 \pm 0.13$ & $1.09 \pm 0.13$ \\
\hline Nitrogen retention (\% of intake) & $21.5 \pm 2.7$ & $19.2 \pm 2.7$ & $18.2 \pm 1.7$ & $18.7 \pm 3.3$ \\
\hline
\end{tabular}

Values presented as means \pm standard deviation $( \pm \mathrm{SD})(n=3)$

$A B W$, average body weight (initial body weight + final body weight) $/ 2$

${ }^{\mathrm{a}}$ Mortality: (number of dead fish $\times 100$ )/number of initial fish

b Feed efficiency (FE): wet weight gain/dry feed intake

${ }^{\mathrm{C}}$ Protein efficiency ratio (PER): wet weight gain/crude protein intake

Means with different lower case letters denotes for significant differences between diets $(P<0.05)$

Whole-body protein, ash, hepatosomatic index (HSI), visceral somatic index (VSI), liver lipid and glycogen were not affected $(P>0.05)$ by diet composition, while whole-body dry matter was lower in fish fed with Chondrus diet, and whole-body lipid content was lower in fish fed with both Chondrus and Mix diets (Table $\underline{3}$ ).

Table 3 Whole-body, liver composition (wet weight basis), hepatosomatic and visceral indices of gilthead seabream fed with the experimental diets

\begin{tabular}{|c|c|c|c|c|c|}
\hline Diets & Initial & Control & Ulva & Chondrus & Mix \\
\hline \multicolumn{6}{|l|}{ Body } \\
\hline Dry matter (\%) & 25.0 & $30.72 \pm 0.49 b$ & $30.06 \pm 0.62 a b$ & $28.67 \pm 0.90 \mathrm{a}$ & $29.29 \pm 0.56 \mathrm{ab}$ \\
\hline Protein (\%) & 15.2 & $16.20 \pm 0.03$ & $16.19 \pm 0.04$ & $16.10 \pm 0.25$ & $16.40 \pm 0.52$ \\
\hline Lipid (\%) & 6.1 & $10.93 \pm 0.35 b$ & $10.25 \pm 0.88 a b$ & $8.82 \pm 0.87 a$ & $9.05 \pm 0.57 a$ \\
\hline Ash (\%) & 5.5 & $4.19 \pm 0.35$ & $4.35 \pm 0.11$ & $4.48 \pm 0.23$ & $4.34 \pm 0.06$ \\
\hline VSI $(\%)^{\mathrm{a}}$ & - & $7.35 \pm 1.03$ & $7.43 \pm 0.84$ & $6.92 \pm 0.62$ & $7.56 \pm 0.88$ \\
\hline $\mathrm{HSI}(\%)^{\mathrm{b}}$ & - & $1.33 \pm 0.21$ & $1.18 \pm 0.17$ & $1.27 \pm 0.19$ & $1.22 \pm 0.26$ \\
\hline \multicolumn{6}{|l|}{ Liver } \\
\hline Lipid (\%) & - & $8.91 \pm 3.96$ & $10.45 \pm 3.30$ & $6.67 \pm 1.77$ & $11.44 \pm 5.04$ \\
\hline Glycogen (\%) & - & $9.22 \pm 1.85$ & $9.28 \pm 0.64$ & $9.36 \pm 3.62$ & $8.60 \pm 1.23$ \\
\hline
\end{tabular}

Values presented as means \pm standard deviation $( \pm$ SD), body $(n=3)$ liver lipid and glycogen $(n=6)$, VSI and HSI $(n=9)$

${ }^{a}$ Visceral somatic index: (viscera weight/body weight) $\times 100$

${ }^{\mathrm{b}}$ Hepatosomatic index: (liver weight/body weight) $\times 100$

Means with different lower case letters denotes for significant differences between diets $(P<0.05)$

Muscle lipid content was unaffected $(P>0.05)$ by dietary composition, but muscle fatty acid profile changed between diets (Table 4 ). $\Sigma$ SFA (saturated fatty acids) increased while

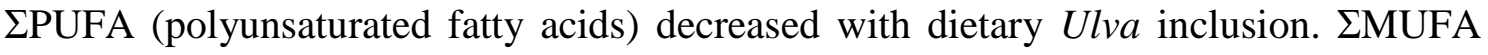
(monounsaturated fatty acids) increased while $\Sigma$ PUFA, $\Sigma \omega 3$, EPA (C20:5 n-3, eicosapentaenoic acid) and DHA (C22:6 n-3, docosahexaenoic acid) decreased with dietary Chondrus inclusion. Muscle fatty acid profile in fish fed with Mix diet was similar with fish fed with Chondrus diet despite for $\Sigma$ SFA that was also increased in fish fed with the Mix diet.

Table 4 Muscle total lipids and ARA, EPA, DHA, $\sum$ SFA, $\sum$ MUFA, $\sum$ PUFA, $\sum \omega 3$ and $\sum \omega 6$ profile (\% of total fatty acids) of gilthead seabream fed with the experimental diets 


\begin{tabular}{|c|c|c|c|c|}
\hline Diets & Control & Ulva & Chondrus & Mix \\
\hline Lipid (\%) & $5.70 \pm 1.59$ & $5.58 \pm 2.23$ & $4.83 \pm 0.93$ & $6.12 \pm 3.02$ \\
\hline$\Sigma$ SFA & $25.4 \pm 0.6 \mathrm{a}$ & $27.2 \pm 1.3 b$ & $26.9 \pm 1.0 \mathrm{ab}$ & $27.2 \pm 1.0 \mathrm{~b}$ \\
\hline EMUFA & $37.0 \pm 0.4 \mathrm{a}$ & $36.9 \pm 1.1 \mathrm{a}$ & $39.2 \pm 0.4 \mathrm{~b}$ & $39.5 \pm 1.3 b$ \\
\hline ¿PUFA & $37.6 \pm 0.6 \mathrm{c}$ & $35.9 \pm 0.8 b$ & $33.9 \pm 0.8 \mathrm{a}$ & $33.3 \pm 0.7 a$ \\
\hline$\Sigma \omega 3$ & $25.3 \pm 0.5 b$ & $24.4 \pm 0.9 \mathrm{~b}$ & $21.4 \pm 0.5 a$ & $20.8 \pm 1.4 a$ \\
\hline EPA (C20:5n-3) & $6.49 \pm 0.29 b$ & $6.17 \pm 0.59 b$ & $4.91 \pm 0.19 a$ & $4.75 \pm 0.51 \mathrm{a}$ \\
\hline DHA (C22:6n-3) & $11.7 \pm 0.5 b$ & $11.7 \pm 0.6 \mathrm{~b}$ & $9.4 \pm 0.7 \mathrm{a}$ & $9.0 \pm 1.0 \mathrm{a}$ \\
\hline$\Sigma \omega 6$ & $12.3 \pm 0.2$ & $11.5 \pm 0.7$ & $12.5 \pm 0.5$ & $12.5 \pm 1.0$ \\
\hline ARA $(C 20: 4 n-6)$ & $0.80 \pm 0.05$ & $0.66 \pm 0.18$ & $0.79 \pm 0.08$ & $0.78 \pm 0.12$ \\
\hline
\end{tabular}

Values presented as means \pm standard deviation $( \pm \operatorname{SD})(n=6)$

Means with different lower case letters denotes for significant differences between diets $(P<0.05)$

Plasmatic cholesterol and total protein were not affected $(P>0.05)$ by dietary seaweed inclusion (Table 5). Plasma triglycerides were higher in fish fed with Chondrus than in fish fed with the Mix diet. Plasma glucose was lower in fish fed with the experimental diets than the Control diet.

Table 5 Plasmatic cholesterol, glucose, triglycerides $\left(\mathrm{mg} \mathrm{dL}^{-1}\right)$ and total protein $(\mathrm{g}$ $\mathrm{dL}^{-1}$ ) of gilthead seabream fed with the experimental diets

\begin{tabular}{|c|c|c|c|c|}
\hline Diets & Control & Ulva & Chondrus & Mix \\
\hline Cholesterol & $147.7 \pm 19.9$ & $145.3 \pm 21.7$ & $134.6 \pm 30.4$ & $126.0 \pm 20.1$ \\
\hline Glucose & $87.2 \pm 18.4 b$ & $68.4 \pm 6.1 \mathrm{a}$ & $63.3 \pm 5.3 \mathrm{a}$ & $64.7 \pm 8.0 \mathrm{a}$ \\
\hline Triglycerides & $315.8 \pm 63.6 a b$ & $376.2 \pm 119.8 \mathrm{ab}$ & $413.7 \pm 114.4 \mathrm{~b}$ & $269.8 \pm 88.8 \mathrm{a}$ \\
\hline Total Protein & $3.33 \pm 0.32$ & $3.19 \pm 0.24$ & $3.24 \pm 0.34$ & $3.16 \pm 0.37$ \\
\hline
\end{tabular}

The activity of liver HK, GK, PBPase, G6PD and ME was not affected $(P>0.05)$ by diet composition, while $\mathrm{PK}$ and HOAD activities were reduced in fish fed with Mix diet (Table $\underline{6}$ ).

Table 6 Specific activities ( $\mathrm{mU} \mathrm{mg}^{-1}$ protein) of hepatic glycolytic (hexokinase, HK, glucokinase, GK and pyruvate kinase, PK), gluconeogenic (fructose 1,6bisphosphatase, PBPase) and lipogenic enzymes (glucose-6-phosphate dehydrogenase, G6PD, malic enzyme, ME and $\beta$-hydroxyacyl-CoA dehydrogenase, HOAD) of gilthead seabream fed with the experimental diets

\begin{tabular}{|l|c|c|c|c|}
\hline Diets & Control & Ulva & Chondrus & Mix \\
\hline HK & $4.56 \pm 1.57$ & $4.05 \pm 1.71$ & $4.24 \pm 0.70$ & $5.35 \pm 2.20$ \\
\hline GK & $5.56 \pm 3.10$ & $3.01 \pm 1.26$ & $3.56 \pm 0.74$ & $4.10 \pm 1.24$ \\
\hline PK & $20.6 \pm 6.0 \mathrm{~b}$ & $15.1 \pm 4.5 \mathrm{ab}$ & $17.5 \pm 5.5 \mathrm{ab}$ & $9.9 \pm 7.7 \mathrm{a}$ \\
\hline PBPase & $27.3 \pm 4.8$ & $22.7 \pm 6.5$ & $24.7 \pm 4.4$ & $21.6 \pm 5.1$ \\
\hline G6PD & $114.5 \pm 26.5$ & $98.4 \pm 20.0$ & $107.4 \pm 14.3$ & $94.2 \pm 38.1$ \\
\hline ME & $3.96 \pm 0.74$ & $3.90 \pm 1.68$ & $4.24 \pm 0.93$ & $5.02 \pm 2.63$ \\
\hline HOAD & $20.8 \pm 4.3 \mathrm{~b}$ & $17.2 \pm 1.6 \mathrm{ab}$ & $17.6 \pm 1.8 \mathrm{ab}$ & $12.5 \pm 6.6 \mathrm{a}$ \\
\hline
\end{tabular}

Values presented as means \pm standard deviation $( \pm \mathrm{SD})(n=6)$

Means with different lower case letters denotes for significant differences between diets $(P<0.05)$

Liver LPO was negatively affected with both dietary algae inclusion, while the activities of antioxidant enzymes were not affected $(P>0.05)$ by the dietary treatments (Table $\underline{7})$. 
Table 7 Specific activities of liver antioxidant enzymes (superoxide dismutase, SOD $\left(\mathrm{U} \mathrm{mg}^{-1}\right.$ protein), catalase, CAT, glutathione peroxidase, GPX, glutathione reductase, GR, (mU mg ${ }^{-1}$ protein)) and liver lipid peroxidation (LPO) (nmol MDA $\mathrm{g}^{-1}$ tissue) levels of gilthead seabream fed with the experimental diets

\begin{tabular}{|c|c|c|c|c|}
\hline Diets & Control & Ulva & Chondrus & Mix \\
\hline$S O D$ & $136.2 \pm 17.6$ & $122.3 \pm 32.1$ & $151.6 \pm 28.1$ & $138.0 \pm 28.8$ \\
\hline CAT & $69.4 \pm 14.5$ & $77.3 \pm 35.3$ & $60.9 \pm 8.2$ & $74.5 \pm 22.1$ \\
\hline GPX & $47.2 \pm 22.8$ & $44.9 \pm 14.4$ & $35.5 \pm 12.6$ & $49.6 \pm 26.0$ \\
\hline GR & $8.40 \pm 2.00$ & $7.54 \pm 2.14$ & $7.28 \pm 1.43$ & $9.52 \pm 2.36$ \\
\hline LPO & $13.2 \pm 1.8 \mathrm{a}$ & $29.4 \pm 5.2 b$ & $38.4 \pm 8.7 b$ & $37.1 \pm 9.0 b$ \\
\hline
\end{tabular}

Values presented as means \pm standard deviation $( \pm \mathrm{SD})(n=6)$

Means with different lower case letters denotes for significant differences between diets $(P<0.05)$

No differences were noticed among groups $(P>0.05)$ on the intestinal morphology, height or density of the intestinal villous (Fig. 1 and Table $\underline{8}$ ). Dietary treatments do not compromise epithelial integrity which was similar among groups, with no signs of hypertrophy or hyperplasia of the goblet cells and a similar number of intraepithelial leucocytes. The lamina propria was thin, without increased cellularity and the submucosa showed similar width in all groups.

Fig. 1
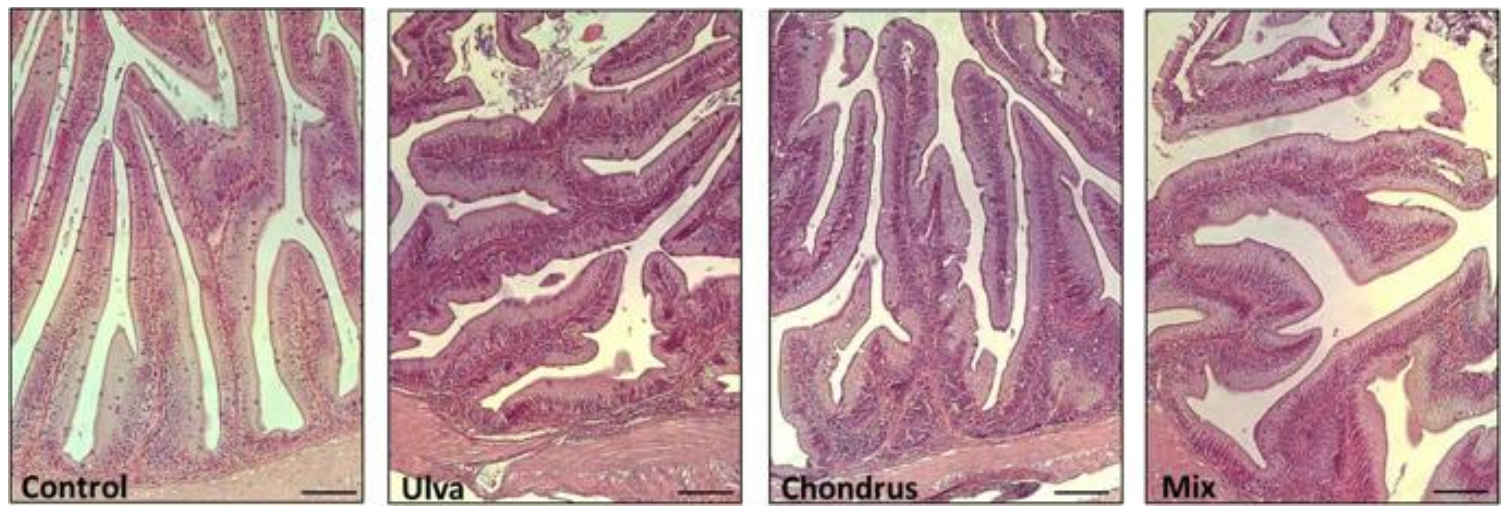

Histomorphology of the distal intestine of gilthead seabream fed with the experimental diets $(H \& E$ staining; scale bar $=100 \mu \mathrm{m})$

Table 8 Intestinal histology of distal intestine (DI) of gilthead seabream fed with the experimental diets 


\begin{tabular}{|c|c|c|c|c|}
\hline Diets & Control & Ulva & Chondrus & Mix \\
\hline $\mathrm{FH}$ & $2.50 \pm 0.55$ & $2.50 \pm 0.55$ & $2.67 \pm 0.52$ & $2.33 \pm 0.52$ \\
\hline LP & $1.33 \pm 0.52$ & $1.33 \pm 0.52$ & $1.33 \pm 0.52$ & $1.17 \pm 0.41$ \\
\hline SM & $1.00 \pm 0.00$ & $1.00 \pm 0.00$ & $1.00 \pm 0.00$ & $1.00 \pm 0.00$ \\
\hline IEL & $1.83 \pm 0.98$ & $1.17 \pm 0.41$ & $2.50 \pm 0.84$ & $2.00 \pm 1.10$ \\
\hline ENT & $1.33 \pm 0.52$ & $1.33 \pm 0.82$ & $1.33 \pm 0.82$ & $1.50 \pm 0.84$ \\
\hline Mean & $1.60 \pm 0.58$ & $1.47 \pm 0.59$ & $1.77 \pm 0.76$ & $1.60 \pm 0.56$ \\
\hline
\end{tabular}

Values presented as means \pm standard deviation $( \pm \mathrm{SD})(n=6)$. Score from o to 5 , with 5 indicating major alterations

ENT: changes in enterocytes nucleous position and vacuolization; FH: shortening, widening and fusion of intestinal folds; IEL: infiltration of

inflammatory cells; LP: connective tissue hyperplasia in the lamina propria; SM: connective tissue hyperplasia in the submucosa

Mean scores were calculated by averaging the scores of the separate parameters evaluated

No statistically significant differences were found

\section{Discussion}

Seaweeds may be used both as an alternative protein source and as a functional ingredient (Wassef et al. 2001, 2013; Ergün et al. 2009; Lozano et al. 2016; Zhu et al. 2016). Though several studies state that dietary seaweed incorporation at high levels $(>10 \%)$ might negatively affect fish performance (Valente et al. 2006; Azaza et al. 2008; Marinho et al. 2013; Silva et al. 2015; Zhu et al. 2016; Sotoudeh and Mardani 2018), in the present study, dietary $C$. crispus incorporation at low level (5\%) already reduced fish performance. The lower growth observed was not related to lower feed intake as previously reported (Silva et al. 2015), since feed intake was similar among treatments. This suggests that seaweeds tested did not alter feed palatability for gilthead seabream. The relative low nutritive value of some seaweeds was also advanced to explain the negative effects observed on growth performance (Valente et al. 2006). However, this seems to occur when seaweeds are incorporated in the diets at higher levels than the ones used in the present study. For instance, for rainbow trout (Oncorhynchus mykiss) and Nile tilapia, diets incorporating $30 \%$ of seaweeds (Porphyra dioica, Ulva spp., G. vermiculophylla and Sargassum muticum) have a lower digestibility than a reference diet, though the reported digestibility values were still considerably high (Pereira et al. 2012).

The presence of antinutrional factors, such as saponins, tannins, phytic acid, xylans, agar and alginates may negatively affect the nutritional quality and nutrients digestion/absorption of seaweeds and consequently, may reduce growth performance (Dallaire et al. 2007; Azaza et al. 2008; Marinho et al. 2013; Silva et al. 2015). In accordance, Sáez et al. (2013) reported that $U$. rigida contains antinutrients that reduce digestive proteolytic activity of gilthead seabream up to $77 \%$, producing a generalised inhibition of alkaline proteases activity, though fish was able to compensate that inhibition and no effect on growth was observed.

Future studies should assess if the removal or breakdown of complex carbohydrates present in seaweeds might improve fish growth performance. In fact, the addition of nonstarch polysaccharide-degrading enzymes on seaweed-containing diets (U. prolifera, $G$. lemaneiformis or U. pertusa), for rabbitfish (Siganus canaliculatus), improved growth when compared with diets without enzyme supplementation (Xie et al. 2018). 
Though growth performance was reduced with dietary C. crispus incorporation, proteinefficiency ratio and nitrogen retention were not affected by dietary treatments, which is in accordance with what was also observed in European seabass fed with Gracilaria bursa-pastoris, $U$. rigida and G. cornea replacing 5 and $10 \%$ of fish protein hydrolysate (Valente et al. 2006). On the contrary, in Nile tilapia fed 10, 15 or $20 \%$ of Ulva spp. replacing fish meal, lower protein retention was observed in fish with the lowest growth rate (Marinho et al. 2013).

Contrary to the present study, where dietary incorporation of $U$. lactuca had no effect on the body lipid composition, $U$. rigida incorporated at $5 \%$ in Nile tilapia diets or at $25 \%$ in gilthead seabream diets lead to a reduction in body lipids (Ergün et al. 2009; Vizcaíno et al. 2016). In the present study, it was Chondrus and the Mix diet that led to a reduction of body lipid content, and this may be related to the lower body weight of fish fed with these diets. Seaweeds are major sources of EPA and DHA, with red seaweeds having significant amounts of PUFA's such as EPA and ARA (arachidonic acid), while oleic acid and linolenic acid are found in high amounts in green seaweeds (Holdt and Kraan 2011). Due to the low lipid content of both seaweeds used in the present study and the low incorporation in the diets, no significant changes were expected in muscle fatty acid composition. Nonetheless, several differences were found in the fatty acid muscle composition between dietary treatments in the present study, with dietary C. crispus and the mix of seaweeds incorporation having the highest impact, particularly regarding EPA and DHA content. Since no differences were observed on the muscle composition, total lipids and only the fatty acids composition were affected, this deserves to be further studied.

To the authors' knowledge, this is the first study in fish assessing the effect of seaweeds in carbohydrate and lipid intermediary metabolism. Dietary seaweeds had no effect on fatty acid biosynthesis, as inferred by similar G6PD and ME activities. This is in accordance with the lack of effect or even reduction of whole-body lipid content of fish fed the Chondrus and Mix diets. Accordingly, HOAD activity, an enzyme involved in fatty acid $\beta$-oxidation, was also reduced in fish fed the Mix diet. In agreement with the present study, rats fed with Undaria pinnatifida at 5 and $10 \%$ presented unchanged ME activity, though G6PD activity was decreased (Murata et al. 1999). Regarding the enzymes involved in fatty acid oxidation, the authors also observed in rats an increase in all the enzymes analysed except for HOAD that was unchanged. Gluconeogenic activity was also not affected by dietary seaweeds incorporation, which is in agreement with the lack of differences between groups in liver glycogen content. The lower starch level in the algae containing diets might explain the lower PK activity observed in fish fed with Mix and the trend for a reduced activity of both PK and GK activities in the experimental diets. This may also contribute to explain the lower plasmatic glucose in fish fed with the experimental diets.

Seaweeds contain bioactive compounds with great antioxidant activity, for instance, $U$. lactuca contains among others ulvan, and phlorotannins, while C. crispus contains 
carrageenan, and $\beta$-carotenes (Holdt and Kraan 2011). However, in the present study, no effect of seaweeds supplementation was observed in liver antioxidant enzymatic activities, while liver LPO increased in fish fed with seaweeds, indicating an increased oxidative stress. Similar results were also observed in European seabass fed with $7.5 \%$ Gracilaria spp. or a mix of $2.5 \%$ of each species of seaweed: Gracilaria spp., Ulva spp. and Fucus spp. (Peixoto et al. 2016b). The authors suggested that seaweed supplementation increases cellular lipid layer degradation, thus increasing oxidative stress. On the contrary, several studies already reported beneficial effects of using seaweeds to improve fish oxidative status. For instance, Magnoni et al. (2017) reported in gilthead seabream fed with $5 \%$ G. vermiculophylla and U. lactuca a decreased liver LPO in fish recovering from a hypoxia challenge. Moreover, European seabass fed with 2.5 or $7.5 \%$ Gracilaria spp., Ulva spp. or Fucus spp., and meagre (Argyrosomus regius) infected with Photobacterium damselae subsp. piscicida fed with 5\% Gracilaria spp. or Alaria spp. presented also improved oxidative status (Peixoto et al. 2016a; Peixoto et al. 2017). Even though these species belong to a higher trophic level than gilthead seabream, we have to keep in mind that in those studies, the seaweeds were previously thermally processed (Magnoni et al. 2017), being all extruded diets (Peixoto et al. 2016a; Magnoni et al. 2017; Peixoto et al. 2017). Seaweeds processing and dietary extrusion remove or break some of the complex carbohydrates present in the seaweeds allowing fish to access them.

In the present study, no effect of dietary seaweed inclusion was observed in distal intestine histomorphology. Similarly, gilthead seabream fed until $25 \%$ of G. cornea or U. rigida meal had no histological alterations on the proximal and distal intestinal structure (Vizcaíno et al. 2016). In agreement, Silva et al. (2015) also observed no effect of Ulva spp. in Nile tilapia proximal intestine morphology, while two other seaweeds: $P$. dioica and $G$. vermiculophylla, lead to villi length reduction, and G. vermiculophylla also reduced intestine diameter. Similarly, in rainbow trout fed diets with 3 and 5\% Gracilaria pygmaea morphology of anterior intestine and pyloric caeca was normal, while in fish fed 9 and $12 \%$ of the seaweed intestine villi height and absorptive area were decreased (Sotoudeh and Mardani 2018). Seaweeds effect on intestinal histomorphology might be affected by species of fish, species of fed seaweed, diet processing (dry pelleted or extruded) or even other ingredients included on diets.

In conclusion, under present experimental conditions, no beneficial effects of including $U$. lactuca or C. crispus in the diets for gilthead seabream juveniles was observed. Growth performance was even depressed with dietary inclusion of C. crispus or the mix of seaweeds, and hepatic oxidative status was negatively affected in all dietary treatments.

\section{References}

1. AOAC (2000) Official methods of analysis. Association of Official Analytical Chemists, Gaithersburg, Maryland, USA 
2. Arias A (1980) Crescimiento, régimen alimenterio y reproduccion de la dorada (Sparus aurata L.) y del robalo (Dicentrarchus labrax L.) en los esteros de Cádiz. Inv Pesq 44:59-83

3. Azaza MS, Mensi F, Ksouri J, Dhraief MN, Brini B, Abdelmouleh A, Kraïem MM (2008) Growth of Nile tilapia (Oreochromis niloticus L.) fed with diets containing graded levels of green algae ulva meal (Ulva rigida) reared in geothermal waters of southern Tunisia. J Appl Ichthyol 24:202-207

4. Baeverfjord G, Krogdahl $\AA$ (1996) Development and regression of soybean meal induced enteritis in Atlantic salmon distal intestine. A comparison with the intestines of fasted fish. J Fish Dis 19:375-387

5. Beutler HO (1984) Starch. In: Bergmeyer HU (ed) Methods of enzymatic analysis, vol 6. Verlag Chemie, Weinheim, pp 2-10

6. Bondia-Pons I, Moltó-Puigmartí C, Castellote AI, López-Sabater MC (2007) Determination of conjugated linoleic acid in human plasma by fast gas chromatography. J Chromatogr A 1157:422-429

7. Bradford MM (1976) A rapid and sensitive method for the quantitation of microgram quantities of protein utilizing the principle of protein-dye binding. Anal Biochem 72:248-254

8. Collén J, Cornish ML, Craigie J, Ficko-Blean E, Hervé C, Krueger-Hadfield SA, Leblanc C, Michel G, Potin P, Tonon T, Boyen C (2014) Chondrus crispus - a present and historical model organism for red seaweeds. Adv Bot Res 71:53-89

9. Couto A, Barroso C, Guerreiro I, Pousão-Ferreira P, Matos E, Peres H, OlivaTeles A, Enes P (2016) Carob seed germ meal in diets for meagre (Argyrosomus 
regius) juveniles: growth, digestive enzymes, intermediary metabolism, liver and gut histology. Aquaculture 451:396-404

10. Dallaire V, Lessard P, Vandenberg G, de la Noüe J (2007) Effect of algal incorporation on growth, survival and carcass composition of rainbow trout (Oncorhynchus mykiss) fry. Bioresour Technol 98:1433-1439

11. Emre Y, Ergün S, Kurtoğlu A, Güroy B, Güroy D (2013) Effects of Ulva meal on growth performance of gilthead seabream (Sparus aurata) at different levels of dietary lipid. Turk J Fish Aquat Sci 13:841-846

12. Ergün S, Soyutürk M, Güroy B, Güroy D, Merrifield D (2009) Influence of Ulva meal on growth, feed utilization, and body composition of juvenile Nile tilapia (Oreochromis niloticus) at two levels of dietary lipid. Aquacult Int 17:355-361

13. Folch J, Lees M, Sloane-Stanley GHS (1957) A simple method for the isolation and purification of total lipids from animal tissue. J Biol Chem 226:497-509

14. Guerreiro I, Peres H, Castro C, Pérez-Jiménez A, Castro-Cunha M, Oliva-Teles A (2014a) Water temperature does not affect protein sparing by dietary carbohydrate in Senegalese sole (Solea senegalensis) juveniles. Aquac Res 45:289-298

15. Guerreiro I, Pérez-Jiménez A, Costas B, Oliva-Teles A (2014b) Effect of temperature and short chain fructooligosaccharides supplementation on the hepatic oxidative status and immune response of turbot (Scophthalmus maximus). Fish Shellfish Immunol 40:570-576

16. Holdt SL, Kraan S (2011) Bioactive compounds in seaweed: functional food applications and legislation. J Appl Phycol 23:543-597 
17. Kiron V (2012) Fish immune system and its nutritional modulation for preventive health care. Anim Feed Sci Technol 173:111-133

18. Krogdahl Å, Bakke-McKellep AM, Baeverfjord G (2003) Effects of graded levels of standard soybean meal on intestinal structure, mucosal enzyme activities, and pancreatic response in Atlantic salmon (Salmo salar L.). Aquac Nutr 9:361-371

19. Kulshreshtha G, Rathgeber B, Stratton G, Thomas N, Evans F, Critchley A, Hafting J, Prithiviraj B (2014) Feed supplementation with red seaweeds, Chondrus crispus and Sarcodiotheca gaudichaudii, affects performance, egg quality, and gut microbiota of layer hens. Poult Sci 93:2991-3001

20. Liu J, Hafting J, Critchley AT, Banskota AH, Prithiviraj B (2013) Components of the cultivated red seaweed Chondrus crispus enhance the immune response of Caenorhabditis elegans to Pseudomonas aeruginosa through the pmk-1, daf2/daf-16, and skn-1 pathways. Appl Environ Microbiol 79:7343-7350

21. Lozano I, Wacyk JM, Carrasco J, Martín MAC-S (2016) Red macroalgae Pyropia columbina and Gracilaria chilensis: sustainable feed additive in the Salmo salar diet and the evaluation of potential antiviral activity against infectious salmon anemia virus. J Appl Phycol 28:1343-1351

22. Magnoni LJ, Martos-Sitcha JA, Queiroz A, Calduch-Giner JA, Gonçalves JFM, Rocha CMR, Abreu HT, Schrama JW, Ozorio ROA, Pérez-Sánchez J (2017) Dietary supplementation of heat-treated Gracilaria and Ulva seaweeds enhanced acute hypoxia tolerance in gilthead sea bream (Sparus aurata). Open Biol 6:897908

23. Makkar HPS, Tran G, Heuzé V, Giger-Reverdin S, Lessire M, Lebas F, Ankers P (2016) Seaweeds for livestock diets: a review. Anim Feed Sci Technol 212:1-17 
24. Marinho G, Nunes C, Sousa-Pinto I, Pereira R, Rema P, Valente LMP (2013) The IMTA-cultivated Chlorophyta Ulva spp. as a sustainable ingredient in Nile tilapia (Oreochromis niloticus) diets. J Appl Phycol 25:1359-1367

25. Murata M, Ishihara K, Saito H (1999) Hepatic fatty acid oxidation enzyme activities are stimulated in rats fed the brown seaweed, Undaria pinnatifida (Wakame). J Nutr 129:146-151

26. Oliva-Teles A (2012) Nutrition and health of aquaculture fish. J Fish Dis 35:83108

27. Ortiz J, Romero N, Robert P, Araya J, Lopez-Hernández J, Bozzo C, Navarrete E, Osorio A, Rios A (2006) Dietary fiber, amino acid, fatty acid and tocopherol contents of the edible seaweeds Ulva lactuca and Durvillaea antarctica. Food Chem 99:98-104

28. Peixoto MJ, Salas-Leitón E, Pereira LF, Queiroz A, Magalhães F, Pereira R, Abreu H, Reis PA, Gonçalves JFM, Ozório ROA (2016a) Role of dietary seaweed supplementation on growth performance, digestive capacity and immune and stress responsiveness in European seabass (Dicentrarchus labrax). Aquac Rep 3:189-197

29. Peixoto MJ, Svendsen JC, Malte H, Pereira LF, Carvalho P, Pereira R, Gonçalves JFM, Ozório ROA (2016b) Diets supplemented with seaweed affect metabolic rate, innate immune, and antioxidant responses, but not individual growth rate in European seabass (Dicentrarchus labrax). J Appl Phycol 28:2061-2071

30. Peixoto MJ, Salas-Leitón E, Brito F, Pereira LF, Svendsen JC, Baptista T, Pereira R, Abreu H, Reis PA, Gonçalves JFM, Ozório ROA (2017) Effects of dietary Gracilaria sp. and Alaria sp. supplementation on growth performance, metabolic rates and health in meagre (Argyrosomus regius) subjected to pathogen infection. J Appl Phycol 29:433-447 
31. Pereira R, Valente LMP, Sousa-Pinto I, Rema P (2012) Apparent nutrient digestibility of seaweeds by rainbow trout (Oncorhynchus mykiss) and Nile tilapia (Oreochromis niloticus). Algal Res 1:77-82

32. Pérez-Jiménez A, Hidalgo MC, Morales AE, Arizcun M, Abellán E, Cardenete G (2009) Use of different combinations of macronutrients in diets for dentex (Dentex dentex) effects on intermediary metabolism. Comp Biochem Physiol A $152: 314-321$

33. Pita C, Gamito S, Erzini K (2002) Feeding habits of the gilthead sea bream (Sparus aurata) from the Ria Formosa (southern Portugal) as compared to the black sea bream (Spondyliosoma cantharus) and the annular sea bream (Diplodus annularis). J Appl Ichthyol 18:81-86

34. Plummer DT (1987) An introduction to practical biochemistry. McGraw-Hill Book, London

35. Ribeiro AR, Gonçalves A, Colen R, Nunes ML, Dinis MT, Dias J (2015) Dietary macroalgae is a natural and effective tool to fortify gilthead seabream fillets with iodine: effects on growth, sensory quality and nutritional value Aquaculture 437:51-59

36. Rico RM, Tejedor-Junco MT, Tapia-Paniagua ST, Alarcón FJ, Mancera JM, López-Figueroa F, Balebona MC, Abdala-Díaz RT, Moriñigo MA (2016) Influence of the dietary inclusion of Gracilaria cornea and Ulva rigida on the biodiversity of the intestinal microbiota of Sparus aurata juveniles. Aquac Int 24:965-984

37. Roberfroid MB (2000) Prebiotics and probiotics: are they functional foods? Am J Clin Nutr 71:1682s-1687s

38. Sáez MI, Martínez T, Alarcón J (2013) Effect of dietary inclusion of seaweeds on intestinal proteolytic activity of juvenile sea bream, Sparus aurata. International Aquafeed March-April edition, pp 38-40

39. Shpigel M, Guttman L, Shauli L, Odintsov V, Ben-Ezra D, Harpaz S (2017) Ulva lactuca from an integrated multi-trophic aquaculture (IMTA) biofilter system as a protein supplement in gilthead seabream (Sparus aurata) diet. Aquaculture 481:112-118 
40. Silva DM, Valente LMP, Sousa-Pinto I, Pereira R, Pires MA, Seixas F, Rema P (2015) Evaluation of IMTA-produced seaweeds (Gracilaria, Porphyra, and Ulva) as dietary ingredients in Nile tilapia, Oreochromis niloticus L., juveniles. Effects on growth performance and gut histology. J Appl Phycol 27:1671-1680

41. Sotoudeh E, Mardani F (2018) Antioxidant-related parameters, digestive enzyme activity and intestinal morphology in rainbow trout (Oncorhynchus mykiss) fry fed graded levels of red seaweed, Gracilaria pygmaea. Aquac Nutr 4:777-785

42. Valente LMP, Gouveia A, Rema P, Matos J, Gomes EF, Pinto IS (2006) Evaluation of three seaweeds Gracilaria bursa-pastoris, Ulva rigida and Gracilaria cornea as dietary ingredients in European sea bass (Dicentrarchus labrax) juveniles. Aquaculture 252:85-91

43. Vizcaíno AJ, Mendes SI, Varela JL, Ruiz-Jarabo I, Rico R, Figueroa FL, Abdala R, Moriñigo MA, Mancera JM, Alarcón FJ (2016) Growth, tissue metabolites and digestive functionality in Sparus aurata juveniles fed different levels of macroalgae, Gracilaria cornea and Ulva rigida. Aquac Res 47:3224-3238

44. Wassef EA, El Masry MH, Mikhail FR (2001) Growth enhancement and muscle structure of striped mullet, Mugil cephalus L., fingerlings by feeding algal mealbased diets. Aquac Res 32:315-322

45. Wassef EA, El-Sayed AFM, Kandeel KM, Sakr EM (2005) Evaluation of Pterocladia (Rhodophyta) and Ulva (Chlorophyta) meals as additives to gilthead seabream Sparus aurata diets. Egypt J Aquat Res 31:321-332

46. Wassef EA, El-Sayed A-FM, Sakr EM (2013) Pterocladia (Rhodophyta) and Ulva (Chlorophyta) as feed supplements for European seabass, Dicentrarchus labrax L., fry. J Appl Phycol 25:1369-1376 
47. Xie D, Li X, You C, Wang S, Li Y (2018) Supplementation of macroalgae together with non-starch polysaccharide-degrading enzymes in diets enhanced growth performance, innate immune indexes, and disease resistance against Vibrio parahaemolyticus in rabbitfish Siganus canaliculatus. J Appl Phycol. https://doi.org/10.1007/s10811-018-1662-4

48. Zhu D, Wen X, Xuan X, Li S, Li Y (2016) The green alga Ulva lactuca as a potential ingredient in diets for juvenile white spotted snapper Lutjanus stellatus Akazaki. J Appl Phycol 28:703-711

\section{Acknowledgements}

We would like to express our thanks to P. Correia for the assistance during the growth trial.

\section{Funding}

This work was supported by the Structured R\&D\&I Project INNOVMAR (ref. NORTE01-0145-FEDER-000035) within the research line INSEAFOOD, founded by the Northern Regional Operational Programme (NORTE2020) through the European Regional Development Fund (ERDF). The Fundação para a Ciência e a Tecnologia (FCT) and the FEDER, under programme PT2020 (Project UID/QUI/50006/2013) are also acknowledged for the financial funding. I.G., R.M. and A.C. were supported by FCT grants (SFRH/BPD/114959/2016, SFRH/BD/115870/2016 and SFRH/BPD/101354/2014, respectively). F.C. was a recipient of a grant within the Project ZEBRALGRE (PTDC/CVT-WEL/5207/2014). 